\title{
Unusual Sjögren's Syndrome with Bilateral Parotid Cysts
}

\author{
Bommie Florence Seo, \\ Rock Kuen Ju, \\ Seung-Ki Kwok ${ }^{2}$, \\ Deuk Young $\mathrm{Oh}^{1}$
}

Departments of ${ }^{1}$ Plastic and Reconstructive Surgery and ${ }^{2}$ Rheumatology, College of Medicine, The Catholic University of Korea, Seoul, Korea

No potential conflict of interest relevant to this article was reported.

\begin{abstract}
Sjögren's syndrome is a chronic autoimmune exocrinopathy that destroys salivary and lacrimal gland tissue. We report an unusual case of this disease in a 54-year-old woman who presented with multiple and bilateral parotid cystic masses. The multiple, small, bead-like cysts were clearly evident in the computed tomography sections in this patient, a visible reminder that this may be the initial presentation in a patient with Sjögren's syndrome. As the case illustrates, Sjögren's syndrome should be included in the differential diagnosis of multiple and bilateral cystic parotid lesions.
\end{abstract}

Keywords: Parotid gland / Syndrome / Cysts / Rare diseases

\section{INTRODUCTION}

Sjögren's syndrome is an autoimmune disorder that involves the immune-mediated destruction of the salivary and lacrimal glands, resulting in the loss of tear and saliva production. This report describes a patient with Sjögren's syndrome, whose unusual presentation included multiple parotid cysts.

\section{CASE REPORT}

A 54-year-old woman presented with a progressively enlarging, palpable mass in her right infra-auricular area. She had noticed this mass for about a year. On exam, two nodules, $1 \mathrm{~cm}$ and 0.5 $\mathrm{cm}$ in diameter, were palpated, which were without any signs of infection. During the interview and physcial exam, the patient also reported a 5-year history of dry eyes and a 2-year history of a dry mouth. She was not taking any medications, and did not have

Correspondence: Deuk Young Oh

Department of Plastic and Reconstructive Surgery, Seoul St. Mary's Hospital, College of Medicine, The Catholic University of Korea, 222 Banpodaero, Seocho-gu, Seoul 137-701, Korea

E-mail: ohdeuk1234@hanmail.net

Received July 17, 2014 / Revised July 25, 2014 / Accepted August 3, 2014 any contributing familial factors.

With a provisional diagnosis of Sjögren's syndrome, a computed tomography (CT) study revealed heterogeneous enhancement of both salivary glands with cystic changes, and atrophic changes in both submandibular glands (Fig. 1). The computed tomographic findings were consistent with a chronic connective tissue disorder such as Sjögren's syndrome. Other cystic conditions such as mucocele, branchial cyst, cystic Warthin's tumor, and human immunodeficiency virus (HIV)-related parotid cyst must be ruled out on clinical and histologic grounds [1]. Ultrasonographic findings revealed multiple homogenous, hypoechoic cystic lesions, most of which were $<10 \mathrm{~mm}$ in size, in both parotid glands. Ultrasonography-assisted, fine-needle biopsy performed on the dominant cyst in the right gland was negative for malignancy, but polymorphous lymphoid cells were seen which indicate a benign lymphoepithelial disease consistent with Sjögren's syndrome (Fig. 2). A salivary scan showed that both the parotid and submandibular glands had decreased uptake and secretion, which also was suggestive of Sjögren's syndrome.

Serologic examinations revealed elevated rheumatoid factor levels (40.9 IU/mL), anti-SS-A/Ro antibodies (179 IU/mL), antiSS-B/La antibodies (133 IU/mL), antinuclear antibodies of the 

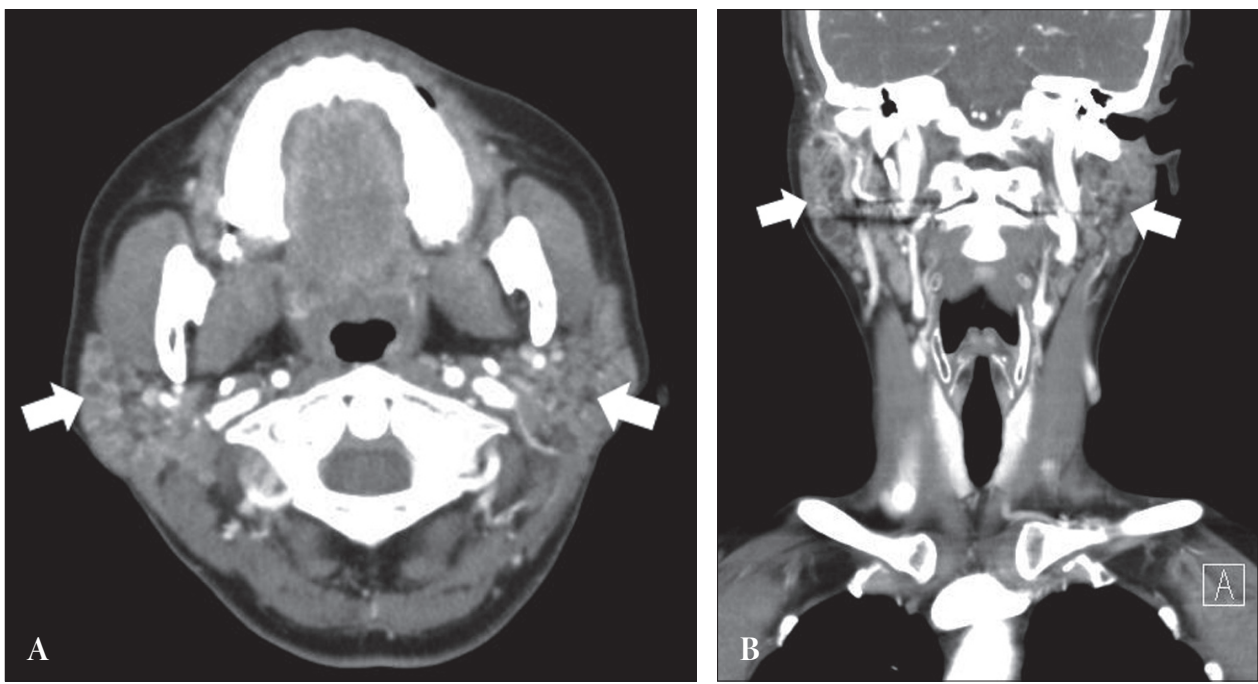

Fig. 1. (A, B) Computed tomography images showing heterogeneous enhancement of both salivary glands (white arrows) with cystic changes and atrophic changes in both submandibular glands.

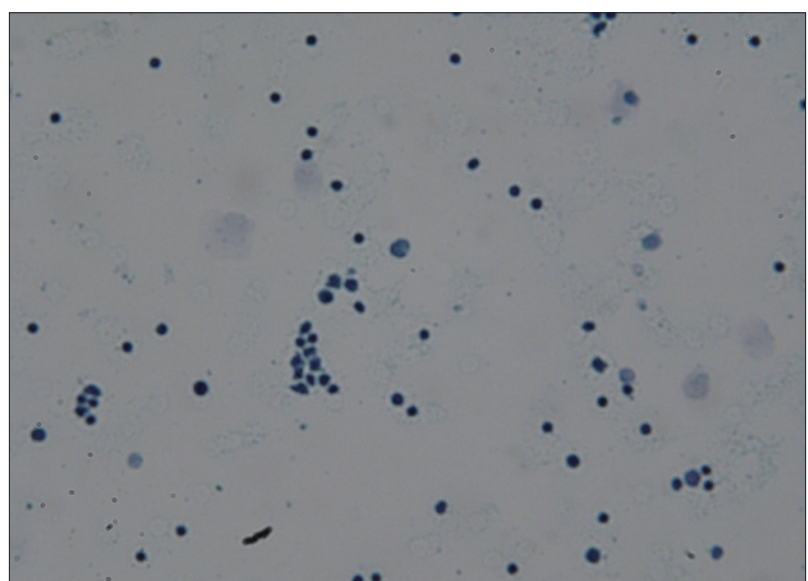

Fig. 2. Cytology findings of the cells obtained via fine needle aspiration. The Papanicolaou smear shows small and large polymorphous lymphoid cells (Papanicolaou smear, $\times 40$ ).

speckled and nucleolar type, and 50\% hemolytic unit of complement (CH50, $56.3 \mathrm{U} / \mathrm{mL})$. Tests for HIV markers were negative. Schirmer tests were positive for both eyes.

The patient was prescribed methylprednisolone, pilocarpine, hydroxychloroquine, artificial tearing agents, and oral hydrating agents. At 3-months of follow-up, oral and ocular symptoms have improved, but parotid masses still remained. Patients with Sjogren's syndrome have greater than 40-fold higher risk of developing lymphoma. We planned regular follow-up for early detection of signs suggestive of lymphoma. Each follow-up visit should include a clinical examination of the neck to look for signs of lymphadenopathy and of the parotid gland to look for asymmetry and changes in size. If a malignancy is suspected on clinical grounds, the patient should undergo a repeat magnetic resonance imaging (MRI) or CT.

\section{DISCUSSION}

Depending on whether Sjögren's syndrome presents alone or coexists with other autoimmune disorders, it may be designated as "primary" or "secondary." Similar disorders include systemic lupus erythematosus, rheumatoid arthritis, polymyositis, and systemic sclerosis [2].

Diagnostic criteria have changed constantly over the years and controversy remains on which criteria are the most accurate. In 2002, the American-European Consensus Group put forth an international criteria: 1) Ocular signs, Shirmer I test positive; 2) Salivary gland biopsy, focus score of 1 or higher (50 or more lymphocytes per 4 square millimeters); 3) Ocular symptoms, subjective sense of dry eyes and/or use of 3 or more tear substitutes per day; 4) Oral symptoms, subjective sense of dry mouth, recurrent of persistent swollen salivary glands, and/or liquid substitute to assist food swallowing; 5) Autoantibodies, anti-SSA (Ro) or anti-SSB (La), or both; 6) Oral signs, unstimulated whole salivary flow, ab- 
normal parotid sialography, abnormal salivary scintigraphy. To qualify for a diagnosis, patients must present with at least 4 of the criteria with either positive serologic studies (positive anti-SSA and/or anti SSB antigen) or positive salivary gland biopsy [3].

Although the most typical symptoms of Sjögren's syndrome are dry eyes and dry mouth, the clinical presentations vary widely. Approximately one-third of patients with primary Sjögren's syndrome also have diffuse parotid gland enlargement, and $80 \%$ of patients experience parotid gland enlargement during their lifetime. However, the presence of multiple, bilateral parotid cysts upon presentation is rare in Sjögren's syndrome; only few such cases have been reported (Table 1) [1,2,4-6]. The main differential diagnoses for bilateral parotid cysts, observed by imaging, are cystic Warthin tumors, HIV-related benign lymphoepithelial lesions, and branchial cysts [1].

Various imaging modalities such as CT, MRI, magnetic resonance sialography, and ultrasonography have been applied to evaluate the pathological changes in the salivary glands. Parotid
MRI images usually reveal multiple, mixed, hypointense, and hyperintense foci, described as a "salt and pepper appearance", which are considered strongly suggestive of Sjögren's syndrome $[2,4,6]$. Sun et al. [7], in their evaluation of the diagnostic accuracy of parotid CT, concluded that heterogeneity, abnormal diffuse fat tissue deposition, and diffuse punctate calcification were specific for Sjögren's syndrome. A small proportion (5.8\%) of patients had presented with well-circumscribed cystic lesions, which were be confirmed as lymphoepithelial cysts. The pathogenesis of abnormal adipose deposition is still unclear and may be related to the destruction and shrinkage of the excretory system. Lymphocytic infiltration, destruction of the acini, and fibrosis characterized the pathological changes, when the major salivary glands were affected in Sjögren's syndrome.

The imaging findings of the patients previously reported with an initial presentation of multiple, bilateral parotid cysts are shown in Table 1. Som et al. [1] described such findings, but did not publish CT and MRI images of multiple cysts. The first report CT im-

Table 1. Information on 6 patients with Sjögren's syndrome with multiple, bilateral parotid cysts reported in the English literature

\begin{tabular}{|c|c|c|c|c|c|c|c|}
\hline Authors & Year & $\mathrm{N}$ & Age & Gender & Clinical findings & Imaging modality and findings & Diagnosis \\
\hline $\begin{array}{l}\text { Som et al. } \\
{[1]}\end{array}$ & 1995 & 2 & $N D$ & ND & ND & $\begin{array}{l}\text { CT, MRI: bilateral multiple, uniformly thin- } \\
\text { walled parotid cysts varying in size from } \\
\text { few millimeters to over } 2 \mathrm{~cm} \text {. Low signal } \\
\text { intensity in T1 weighted MRI images. }\end{array}$ & $\begin{array}{l}\text { Sjögren's } \\
\text { syndrome }\end{array}$ \\
\hline $\begin{array}{l}\text { Ahmad et al. } \\
\text { [4] }\end{array}$ & 1998 & 1 & 15 & Female & $\begin{array}{l}\text { 6-7 month history of painless swelling of left } \\
\text { parotid gland. } \\
\text { Pex: diffuse enlargement of both parotid } \\
\text { glands with discrete mass in left parotid. }\end{array}$ & $\begin{array}{l}\text { MRI: bilateral multiple parotid cysts, bilateral } \\
\text { cystic changes in the submandibular } \\
\text { glands. }\end{array}$ & $\begin{array}{l}\text { Sjögren's } \\
\text { syndrome }\end{array}$ \\
\hline $\begin{array}{l}\text { Plaza et al. } \\
\text { [5] }\end{array}$ & 2003 & 1 & 40 & Female & $\begin{array}{l}6 \text { month history of painless bilateral swelling. } \\
\text { Pex: diffuse enlargement of left parotid gland } \\
\text { with } 2 \mathrm{~cm} \text { nodule, enlargement of right } \\
\text { gland without nodules. }\end{array}$ & $\begin{array}{l}\text { CT: } 18 \text { mm left parotid cyst, enlargement of } \\
\text { both glands. } \\
\text { MRl: multiple cysts in both parotid glands, } \\
\text { hyperintense in T2 weighted images. }\end{array}$ & $\begin{array}{l}\text { Sjögren's } \\
\text { syndrome }\end{array}$ \\
\hline $\begin{array}{c}\text { Toh et al. } \\
\text { [6] }\end{array}$ & 2011 & 1 & 48 & Female & $\begin{array}{l}6 \text { week history of progressive swelling in both } \\
\text { parotid glands. } \\
\text { Pex: diffuse enlargement of both parotid } \\
\text { glands. }\end{array}$ & $\begin{array}{l}\text { MRI: bilateral cysts involving deep and } \\
\text { superficial lobes of parotid glands, low } \\
\text { signal intensity in T1 weighted images, } \\
\text { foci of high signal intensity in T2 wieghted } \\
\text { images. }\end{array}$ & $\begin{array}{l}\text { Sjögren's } \\
\text { syndrome }\end{array}$ \\
\hline $\begin{array}{l}\text { Gadodia et al. } \\
\text { [2] }\end{array}$ & 2012 & 1 & 40 & Female & $\begin{array}{l}3 \text { month history of painless swelling over } \\
\text { both angles of the mandible. } \\
\text { Pex: enlargement of both parotid glands, } \\
2 \times 2 \mathrm{~cm} \text { compressible, nontender, cystic } \\
\text { swelling of the left parotid gland. }\end{array}$ & $\begin{array}{l}\text { CT: bilateral enlarged glands with multiple } \\
\text { variably sized cysts involving both parotid } \\
\text { glands. Atrophied submandibular glands. } \\
\text { MRI: bilateral fatty infiltration of parotid and } \\
\text { submandibular glands. Hyperintense on } \\
\text { T1 and T2 weighted non fat suppressed } \\
\text { images, hypointense on T2 weighted fat } \\
\text { suppressed images. }\end{array}$ & $\begin{array}{l}\text { Sjögren's } \\
\text { syndrome }\end{array}$ \\
\hline
\end{tabular}

N, number; ND, no data; CT, computed tomography; MRI, magnetic resonance imaging; Pex, physical examination. 
age of such a case was by Plaza et al. [5] in 2003. However, these multifocal cysts had not been detected on CT and were found later using MRI. Gadodia et al. [2] also described CT images of enlarged bilateral glands with various cysts, but did not show the images. The multiple, small, bead-like cysts in our case are clearly evident in the CT sections - a visible reminder that this could be the initial presentation in a patient with Sjögren's syndrome.

Sjögren's syndrome is not an uncommon disease, with an estimated prevalence of $1 \%$ to $3 \%$ in the general population. However, surgeons often conduct the initial interview the patients presenting with a swelling or mass-like lesion of the cheek or neck. A Sjögren's syndrome diagnosis requires accurate history taking and requires high clinical suspicion for detection. Although multicystic parotid involvement is rare, this presentation should also trigger suspicion.

\section{REFERENCES}

1. Som PM, Brandwein MS, Silvers A. Nodal inclusion cysts of the parotid gland and parapharyngeal space: a discussion of lymphoepithelial, AIDS-related parotid, and branchial cysts, cystic Warthin's tumors, and cysts in Sjogren's syndrome. Laryngoscope 1995;105:1122-8.

2. Gadodia A, Seith A, Sharma R. Unusual presentation of Sjogren syndrome: multiple parotid cysts. Ear Nose Throat J 2012;91:E17-9.

3. Vitali C, Bootsma H, Bowman SJ, Dorner T, Gottenberg JE, MarietteX, Ramos-Casals M, Ravaud P, Seror R, Theander E, Tzioufas AG. Classification criteria for Sjogren's syndrome: we actually need to definitively resolve the long debate on the issue. Ann Rheum Dis 2013;72:476-8.

4. Ahmad I, Ray J, Cullen RJ, Shortridge RT. Bilateral and multicystic major salivary gland disease: a rare presentation of primary Sjogren's syndrome. J Laryngol Otol 1998;112:1196-8.

5. Plaza G, Dominguez MP, Bueno A. Bilateral parotid cysts as presentation of Sjogren's syndrome. J Laryngol Otol 2003;117:151-2.

6. Toh AS, Broomfield SJ, Teh LS, Aslam MB, Duncan G, Morar P. Bilateral multicystic parotid masses in primary Sjogren syndrome. Ear Nose Throat J 2011;90:E20-2.

7. Sun Z, Zhang Z, Fu K, Zhao Y, Liu D, Ma X. Diagnostic accuracy of parotid CT for identifying Sjogren's syndrome. Eur J Radiol 2012;81: 2702-9. 